\title{
ANALISIS PENGARUH MINAT DAN MOTIVASI TERHADAP KEPUTUSAN MEMILIH PROGRAM STUDI DIMEDIASI OLEH VARIABEL PEKERJAAN YANG DIHARAPKAN
}

\author{
Merta Kusuma \\ Fakultas Ekonomi, Universitas Muhammadiyah Bengkulu, Indonesia \\ mertakusuma99@gmail.com \\ Tezar Arianto \\ Fakultas Ekonomi, Universitas Muhammadiyah Bengkulu, Indonesia \\ tezar.arianto7@gmail.com \\ Meilaty Finthariasari \\ Fakultas Ekonomi, Universitas Muhammadiyah Bengkulu, Indonesia \\ mheyfinta@umb.ac.id
}

\begin{abstract}
Background - This research was conducted based on the research gap ! found by the researcher. Baker (2018) suggests further research to i analyze the expected job variables as a factor in choosing decisions.

Objectives - Analyze the direct and indirect effects between each variable Interest, motivation, and expected work on the decision to choose.

Diterima : 08 Juni 2021

Direview : 10 Juni 2021

Direvisi : 13 Juli 2021

Disetujui : 30 September 2021

Design/ Methodology/ Approach - This research is a descriptive quantitative research. The population in this study were new students in the 2020 academic year at the Faculty of Economics at five universities in Bengkulu City, with a total sample of 356 respondents.

Results and Discussion - The results of this study indicate that the higher the interest of individuals (students) it will encourage them to decide what they want, so it is said that interest is one of the factors that encourage someone to choose something. Likewise, student motivation in studying can be a determinant of their success in the future. The expected job is an important driving factor for students in choosing the faculty they will take in gaining knowledge. This is evidenced by the results of the current study and strengthened by the results of previous studies.

Conclusion - There is a significant effect between each of the expected interest, motivation, and work variables on the decision to choose, with values of $0.596,0.452,0.580$, respectively. Then the work variable which is expected to be able to mediate between the interest and motivation variables on the decision to choose, with values of 0.507 and 0.566 , respectively.

Research Implication - The expected work variables in this study can provide information to each university that is the object of research that is not only related to student internal factors but there are other external factors that have an important contribution to the decision to choose prospective students in determining their choice to take studying.

Research Limitation - This research is limited to the Bengkulu City area with a total sample of 356 respondents and the number of variables studied is only two independent variables (interest and motivation), one mediating variable, and one dependent variable.
\end{abstract}

Keywords : Interest, Motivation, Expected Job, Decision to Choose.

\section{Abstrak}

Latar Belakang - Penelitian ini dilakukan berdasarkan gap riset yang ditemui oleh peneliti. Baker (2018) menyarankan penelitian selanjutnya untuk menganalisis variabel pekerjaan yang diharapkan sebagai factor keputusan memilih. 
Tujuan - Menganalisis pengaruh langsung dan tidak langsung antara masing-masing variable Minat, motivasi, dan pekerjaan yang diharapkan terhadap keputusan memilih.

Desain/ Metodologi/ Pendekatan - Penelitian ini merupakan penelitian kuantitaf deskriptif. Populasi dalam penelitian ini adalah mahasiswa baru tahun akademik 2020 pada Fakultas Ekonomi di lima Universitas yang ada di Kota Bengkulu, dengan jumlah sampel sebesar 356 responden

Hasil dan Pembahasan - Hasil penelitian ini menunjukan bahwa semakin tinggi minat individu (mahasiswa) maka akan mendorong mereka untuk memutuskan apa yang mereka inginkan, sehingga dikatakan bahwa minat adalah salah satu factor yang mendorong seseorang untuk memilih sesuatu hal. Begitupun dengan motivasi mahasiswa dalam berkuliah dapat menjadi penentu dalam keberhasilan mereka di masa mendatang. Pekerjaan yang diharapkan merupakan factor pendorong yang penting bagi mahasiswa dalam memilih fakultas yang akan mereka tempuh dalam menimba ilmu. Hal ini dibuktikan dari hasil penelitian saat ini dan diperkuat dengan hasil penelitian sebelumnya.

Kesimpulan - Terdapat pengaruh signifikan antara masing-masing variable minat, motivasi, dan pekerjaan yang diharapkan terhadap keputusan memilih, dengan nilai $\beta$ masing-masing sebesar 0.596, $0.452,0.580$. Kemudian variable pekerjaan yang diharapkan mampu memediasi antara variable minat dan motivasi terhadap keputusan memilih, yaitu dengan nilai $\beta$ masing-masing sebesar 0.507 dan 0.566 .

Implikasi penelitian - Variable pekerjaan yang diharapkan dalam penelitian ini dapat memberikan informasi kepada masing-masing universitas yang menjadi objek penelitian bahwa bukan hanya berkaitan dengan factor internal mahasiswa namun terdapat factor eksternal lain yang memiliki kontribusi penting terhadap keputusan memilih para calon mahasiswa dalam menentukan pilihan mereka menempuh kuliah.

Batasan penelitian - Penelitian ini terbatas hanya dilakukan pada wilayah Kota Bengkulu dengan jumlah sampel penelitian sebanyak 356 responden dan dengan junlah variable yang diteliti hanya dua variable independent (minat dan motivasi), satu variable mediasi (pekerjaan yang diharapkan), dan satu variable dependen (keputusan memilih).

Keywords : Minat, Motivasi, Pekerjaan yang Diharapkan, Keputusan Memilih.

\section{PENDAHULUAN}

Pendidikan merupakan hal yang terpenting dalam kehidupan kita,ini berarti bahwa setiap manusia Indonesia berhak mendapatkannya dan diharapkan untuk selalu berkembang di dalamnya. Pendidikan tidak akan ada habisnya. Pendidikan secara umum mempunyai arti suatu proses kehidupan dalam mengembangkan diri tiap individu untuk dapat hidup dan melangsungkan kehidupan.Sehingga menjadi seorang yang terdidik itu sangat penting.Kita dididik menjadi orang yang berguna baik bagi Negara, Nusa, dan Bangsa. Perguruna tinggi merupakan kelanjutan dari pendidikan menengah yang diselenggarakan untuk menyiapkan peserta didik menjadi anggota masyarakat yang memiliki kemampuan akademik dan profesional yang dapat menerapkan, mengembangkan dan menciptakan ilmu pengetahuan, teknologi dan atau kesenian. Persaingan perguruan tinggi di Indonesia juga semakin ketat tapi tetap dengan tujuan yang sama, yaitu mencerdaskan kehidupan bangsa dan membentuk masyarakat dengan sumber daya manusia yang sangat berkualitas. 
Setiap calon mahasiswa bebas menentukan pilihan mereka untuk memilih fakultas dan program studi yang mereka minati yang tentunya sesuai dengan kemampuan mereka secara akademik maupun secara financial. Namun program studi juga akan diminati berdasarkan reputasi akademik yang dimilikinya serta peluang bidang pekerjaan yang tersedia setelah lulus dari studi tersebut. Salah satu Fakultas yang diminati oleh para mahasiswa adalah Fakultas Ekonomi. Berdasarkan observasi awal yang peneliti lakukan selama kurang lebih tiga minggu, pada beberapa perguruan tinggi yang ada di Provinsi Bengkulu, hasil sebaran data ditunjukkan pada tabel 1 .

Tabel 1

Data Mahasiswa Fakultas Ekonomi Perguruan Tinggi di Wilayah Kota Bengkulu

\begin{tabular}{lccc}
\multicolumn{1}{c}{ Universitas } & Tahun 2018 & Tahun 2019 & Total \\
UMB & 889 & 680 & 1.569 \\
DEHASEN & 793 & 855 & 1.648 \\
UNIB & 386 & 419 & 805 \\
UNIHAZ & 418 & 405 & 823 \\
IAIN & 803 & 882 & 1.685 \\
\hline
\end{tabular}

Sumber : Hasil Olah Penelitian, 2020

Irmawati (2008) menyatakan bahwa factor yang dapat mempengaruhi calon mahasiswa memutuskan untuk memilih program studi adalah karena adanya factor minat yang ada pada diri sendiri, motivasi, pekerjaan yang diharapkan di masa mendatang, dan factor lingkungan belajar. Menurut Finthariasari \& Saputri (2020), minat adalah factor internal utama bagi individu yang akan dapat menentukan seseorang dalam mengambil keputusan. Kemudian biasanya hal ini akan diikuti dengan munculnya motivasi internal yang akan menjadi dorongan yang kuat dalam memilih produk tertentu termasuk memilih menempuh pendidikan di perguruan tinggi.
Setelah factor internal yang kuat ada dalam diri mahasiswa, selanjutnya factor ekternal juga akan berperan dan mempengaruhi seorang mahasiswa dalam berkeputusan, misalnya dorongan orang tua, popularitas perguruan tinggi, pekerjaan yang diharapkan di masa mendatang, factor lingkungan belajar, dan lain sebagainya ('Amaliya, 2018).

Fakultas Ekonomi adalah salah satu Fakultas yang banyak diminati oleh para calon mahasiswa pada perguruan tinggi di Kota Bengkulu. Penelitian ini bertujuan untuk menganalisis beberapa factor yang dapat mempengaruhi keputusan mahasiswa memilih fakultas yang akan 
ditempuhnya selama masa perkuliahan. Merujuk pada penelitian terdahulu Yazici \& Yazici (2010), Baker (2018) dan beberapa peneliti sebelumnya melakukan penelitian terhadap variabel seperti minat, motivasi, dan pekerjaan yang diharapkan. Baker (2018) menyarankan penelitian selanjutnya untuk menganalisis variabel pekerjaan yang diharapkan sebagai factor keputusan memilih untuk menempuh masa studi. Berdasarkan riset gap ini, peneliti menambahkan variabel pekerjaan yang diharapkan untuk mengetahui seberapa besar pengaruhnya terhadap keputusan mahasiswa dalam memilih Fakultas Ekonomi. Adapun tujuan dari penelitian ini adalah untuk menganalisis factor minat dan motivasi terhadap keputusan mahasiswa memilih studi di Fakultas Ekonomi yang dimediasi oleh pekerjaan yang diharapkan.

\section{TINJAUAN PUSTAKA}

\section{Keputusan Memilih}

Keputusan pembelian adalah pemilihan dari dua atau lebih alternatif pilihan keputusan pembelian, artinya bahwa seseorang dapat membuat keputusan, harus tersedia beberapa alternatif pilihan Schiffman \& Kanuk (2004). Finthariasari et al., (2020), Sahetapy (2013), Ekowati (2018) menyatakan bahwa keputusan memilih merupakan suatu proses pengambilan keputusan akan pembelian yang mencakup penentuan apa yang akan dibeli atau tidak melakukan pembelian dan keputusan itu diperoleh dari kegiatan kegiatan sebelumnya. Sahetapy (2013) menyatakan bahwa untuk mengambil keputusan dalam memilih produk adalah melalui proses indikator:

1. Merumuskan/Mendefinisikan Masalah.

2. Pengumpulan Informasi yang Relevan,

3. Mencari Alternatif Tindakan,

4. Analisis Alternatif,

5. Memilih Alternatif Terbaik,

6. Melaksanakan keputusan dan evaluasi hasil.

\section{Pengaruh Minat terhadap Keputusan Memilih}

Minat mempunyai dua aspek yaitu aspek kognitif dan aspek afektif. Aspek kognitif seorang individu dibangun melalui pengalaman pribadi dan apa yang dipelajari di lingkungan seperti di rumah, sekolah dan masyarakat. Aspek afektif juga dibangun dari pengalaman pribadi seseorang tetapi akan tetapi lebih menekankan kepada emosional. Yazici \& Yazici (2010) terdapat enam indicator minat diantaranya: cita-cita, keinginan memilih program studi, keterkaitan memilih program studi, perhatian teman sebaya, prestasi belajar, dan kondisi orang tua.

Fenyves (2019) dan Mahanani (2018) menyatakan bahwa minat memiliki pengaruh yang signifikan terhadap 
keputusan mahasiswa memilih program study yang mereka inginkan. Minat memudahkan mahasiswa untuk lebih konsentrasi terhadap mata kuliah, tanpa minat maka konsentrasi terhadap pelajaran juga sulit dikembangkan dan dipertahankan. Minat seseorang akan timbul jika seseorang memiliki rasa senang, memiliki harapan dan memiliki pandangan akan obyek dan ia akan mencoba untuk mendapatkannya. Sehingga hipotesis yang dibangun adalah H1 : Minat berpengaruh terhadap keputusan memilih

\section{Pengaruh Motivasi terhadap Keputusan Memilih}

Chatfield et al., (2012) menjelaskan bahwa motivasi merupakan suatu proses yang mencerminkan interaksi antara sikap, kebutuhan, persepsi yang timbul pada diri seseorang. Indikator motivasi diantaranya: frekuensi belajar, belajar demi memenuhi kebutuhan, sikap saat menghadapi kesulitan belajar, ketersediaan fasilitas, dan teman sebaya. Hasil penelitian Gusta et al., (2015), Mahanani (2018), Setyawati (2017) menyatakan bahwa motivasi berpengaruh signifikan terhadap keputusan mahasiswa memilih program studi. Motivasi merupakan keseluruhan daya penggerak dari dalam diri siswa yang menimbulkan kegiatan belajar, yang menjamin kelangsungan dari kegiatan belajar dan yang memberikan arah pada kegiatan belajar itu. Sehingga hipotesis yang dibangun adalah

H2 : Motivasi berpengaruh terhadap keputusan memilih

\section{Pengaruh Pekerjaan Yang Diharapkan terhadap Keputusan Memilih}

Mahanani (2018) beberapa indicator pekerjaan yang diharapkan yang dapat mempengaruhi keputusan mahasiswa memilih Fakultas, adalah: jenis pekerjaan yang dituju, kemudahan dalam meraih prestasi (IPK) yang baik diperkuliahan, kesesuaian bidang di perkuliahan dengan pekerjaan yang dituju, kesempatan kerja yang tersedia, dan prioritas dalam mendapatkan pekerjaan. Setiap individu yang telah menyelesaikan sekolah menengah atas kemudian melanjutkan kejenjang studi yang lebih tinggi di perguruan tinggi, tentunya harapannya adalah untuk mendapatkan pekerjaan yang memadai sesuai dengan cita-cita serta pekerjaan yang diharapkan dapat memenuhi kebutuhan hidup di masa yang akan datang. Untuk mendapatkan pekerjaan yang layak, maka harus dipersiapkan dengan matang, salah satunya yaitu dengan menempuh pendidikan S1 dengan program studi yang paling banyak memberikan peluang pekerjaan. Sehingga hipotesis yang dibangun adalah 
H3 : Pekerjaan yang diharapkan berpengaruh terhadap keputusan memilih H4 : Minat berpengaruh terhadap keputusan memilih melalui pekerjaan yang diharapkan

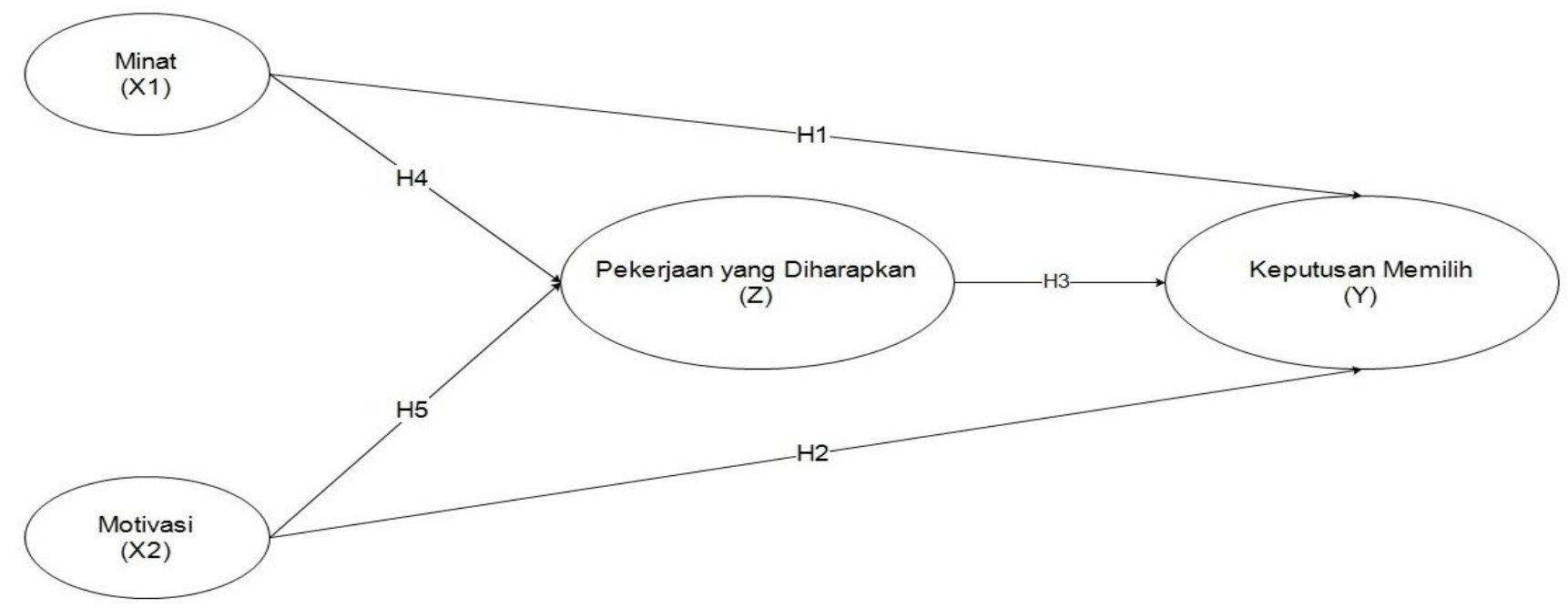

Gambar 1

Kerangka Penelitian

\section{METODOLOGI PENELITIAN}

Penelitian ini merupakan penelitian kuantitaf deskriptif. Populasi dalam penelitian ini adalah mahasiswa baru tahun akademik 2020 pada Fakultas Ekonomi di lima Universitas yang ada di Kota Bengkulu. Sampel ditarik dengan menggunakan rumus Slovin sebanyak 356 responden dengan rincian pada tabel 2 .
H5 : Motivasi berpengaruh terhadap keputusan memilih melalui pekerjaan yang diharapkan 
Tabel 3

Karakteristik Responden Berdasarkan Asal Perguruan Tinggi

\begin{tabular}{rlcccc} 
No & \multicolumn{1}{c}{ Perguruan Tinggi } & \multicolumn{2}{c}{ Jenis Kelamin } & Jumlah & $\%$ \\
& Univ. Bengkulu & 32 & 39 & 71 & 22 \\
2 & IAIN Bengkulu & 22 & 32 & 54 & 17 \\
3 & Univ. Muhammadiyah & 51 & 56 & 107 & 33 \\
& Bengkulu & & & & \multirow{2}{*}{ Perempuan } \\
4 & Univ. Dehasen & 21 & 30 & 51 & 16 \\
5 & Univ. Hazairin & 12 & 27 & 39 & 12 \\
\hline & Total & 138 & 184 & 322 & 100
\end{tabular}

Sumber : Hasil Olah Penelitian, 2021

\section{HASIL DAN PEMBAHASAN}

\section{Hasil Uji Validitas dan Reliabilitas Instrumen}

\section{Penelitian}

Tabel 4 di atas dapat dilihat dari nilai Corrected Item Total Correlation atau nilai untuk masing-masing variabel $>r(0,30)$. Ini menunjukan dari setiap pernyataan kuesioner masing-masing pada variabel adalah valid dan layak untuk digunakan dalam penelitian ini. Artinya item dari setiap pernyataan tersebut mampu mengukur dan menjelaskan variabelnya secara tepat. Tabel 5 dapat diketahui bahwa nilai cronbach alpha untuk ke 4 variabel penelitian yang diteliti memiliki nilai koefisien Cronbach alpha yang lebih besar dari 0,7. Oleh karena itu, dapat disimpulkan bahwa alat ukur atau instrumen yang digunakan dalam penelitian ini adalah reliabel.

\section{Hasil Uji Goodness of Fit}

Tabel 6 Output SPSS menunjukkan untuk pengujian normalitas di atas menunjukkan nilai Asymp. Sig 2 tailed bernilai 0,200 > dari nilai sig statistic sebesar 0,05. Pengujian dilakukan dengan menggunakan nilai residual setiap variabel yang diteliti. Berdasarkan data ditas maka keempat varibael berdistribusi normal, selanjutya dilakukan uji prsyarat menggunakan multikoliniorits dan heterdesitas dan uji hipotesis menggunakan anlisis jalur (path analysis). Dari tabel 7 menunjukan bahwa nilai tolerance $\mathrm{X}_{1}$ dan $\mathrm{X}_{2}$ dan $\mathrm{X}_{3}$ lebih besar dari 0.1 dan nilai VIF $\mathrm{X}_{1}, \mathrm{X}_{2}$ dan $Z$ lebih kecil dari 10 artinya model regresi dikatakan bebas dari masalah multikolinearitas. 
Tabel 4

Uji Validitas

\begin{tabular}{|c|c|c|c|c|}
\hline Variabel & $\begin{array}{c}\text { Item } \\
\text { Pernyataan }\end{array}$ & $\begin{array}{l}\text { Corrected item } \\
\text { total correlation }\end{array}$ & $\mathrm{R}$ & Keterangan \\
\hline \multirow{10}{*}{$\begin{array}{l}\text { X1 } \\
\text { (Minat) }\end{array}$} & 1 & 0,719 & 0,30 & Valid \\
\hline & 2 & 0,720 & 0,30 & Valid \\
\hline & 3 & 0,770 & 0,30 & Valid \\
\hline & 4 & 0,738 & 0,30 & Valid \\
\hline & 5 & 0,758 & 0,30 & Valid \\
\hline & 6 & 0,719 & 0,30 & Valid \\
\hline & 7 & 0,720 & 0,30 & Valid \\
\hline & 8 & 0,770 & 0,30 & Valid \\
\hline & 9 & 0,738 & 0,30 & Valid \\
\hline & 10 & 0,758 & 0,30 & Valid \\
\hline \multirow{12}{*}{$\begin{array}{l}\text { X2 } \\
\text { (Motivasi) }\end{array}$} & 1 & 0,717 & 0,30 & Valid \\
\hline & 2 & 0,710 & 0,30 & Valid \\
\hline & 3 & 0,682 & 0,30 & Valid \\
\hline & 4 & 0,762 & 0,30 & Valid \\
\hline & 5 & 0,776 & 0,30 & Valid \\
\hline & 6 & 0,754 & 0,30 & Valid \\
\hline & 7 & 0,717 & 0,30 & Valid \\
\hline & 8 & 0,710 & 0,30 & Valid \\
\hline & 9 & 0,682 & 0,30 & Valid \\
\hline & 10 & 0,762 & 0,30 & Valid \\
\hline & 11 & 0,776 & 0,30 & Valid \\
\hline & 12 & 0,754 & 0,30 & Valid \\
\hline \multirow{5}{*}{$\begin{array}{l}\text { Z } \\
\text { (Pekerjaan yang } \\
\text { diharapkan) }\end{array}$} & 1 & 0,708 & 0,30 & Valid \\
\hline & 2 & 0,711 & 0,30 & Valid \\
\hline & 3 & 0,763 & 0,30 & Valid \\
\hline & 4 & 0,731 & 0,30 & Valid \\
\hline & 5 & 0,752 & 0,30 & Valid \\
\hline \multirow{6}{*}{$\begin{array}{l}\text { Y } \\
\text { (Keputusan } \\
\text { Mahasiswa } \\
\text { Memilih Fakultas } \\
\text { Ekonomi) }\end{array}$} & 1 & 0,712 & 0,30 & Valid \\
\hline & 2 & 0,701 & 0,30 & Valid \\
\hline & 3 & 0,672 & 0,30 & Valid \\
\hline & 4 & 0,758 & 0,30 & Valid \\
\hline & 5 & 0,772 & 0,30 & Valid \\
\hline & 6 & 0,751 & 0,30 & Valid \\
\hline
\end{tabular}

Sumber : Hasil Olah Penelitian, 2021

Tabel 5

Uji Reliabilitas

\begin{tabular}{lcccc}
\multicolumn{1}{c}{$\begin{array}{c}\text { Nilai Cronbach } \\
\text { Alpha }\end{array}$} & $\begin{array}{c}\text { Cut Of } \\
\text { Falue }\end{array}$ & $\begin{array}{c}\text { Number Of } \\
\text { Item }\end{array}$ & Keterangan \\
Minat Mahasiswa (X1) & 908 & 0,7 & 10 & Reliabel \\
Motivasi Belajar (X2) & 919 & 0,7 & 12 & Reliabel \\
$\begin{array}{l}\text { Pekerjaan yang } \\
\text { Diharapkan (Z) }\end{array}$ & 783 & 0,7 & 5 & Reliabel \\
\hline $\begin{array}{l}\text { Keputusan Mahasiswa } \\
\text { Memilih Prodi Ekonomi (Y) }\end{array}$ & 816 & 0,7 & 6 & Reliabel \\
\hline $\begin{array}{l}\text { Sumber : Hasil Olah Penelitian, 2021 } \\
\text { Sumber }\end{array}$ & & & &
\end{tabular}


Tabel 6

Hasil Uji Normalitas

\begin{tabular}{llr}
\multicolumn{3}{c}{ One-Sample Kolmogorov-Smirnov Test } \\
\hline \multirow{2}{*}{$\begin{array}{l}\text { N } \\
\text { Normal Parameters }{ }^{\mathrm{a}, \mathrm{b}}\end{array}$} & Unstandardized Residual \\
& Mean & 356 \\
\cline { 2 - 3 } & Std. Deviation & .000000000 \\
\hline & Absolute & 1.466 \\
\cline { 2 - 3 } Most Extreme Differences & Positive & 0.062 \\
\cline { 2 - 3 } & Negative & 0.062 \\
\hline Kolmogorov-Smirnov Z & & -0.048 \\
Asymp. Sig. (2-tailed) & & 0.062 \\
\hline a. Test distribution is Normal. & \\
b. Calculated from data. & \\
c. Lilliefors Significance Correction. \\
d. This is a lower bound of the true significance.
\end{tabular}

Tabel 7

Hasil Uji Multikolonearitas

\begin{tabular}{lccl}
\multicolumn{1}{c}{ Variabel } & Tolerance & VIF & Keterangan \\
Minat $\left(\mathrm{X}_{1}\right)$ & 0,164 & 6,106 & Bebas Multikolonearitas \\
Motivasi $\left(\mathrm{X}_{2}\right)$ & 0,608 & 1,645 & Bebas Multikolonearitas \\
Keputusan Memilih $(\mathrm{Y})$ & 0,175 & 5,727 & Bebas Multikolonearitas
\end{tabular}

Sumber : Hasil Olah Penelitian, 2021

Tabel 8

Hasil Uji Heteroskedastisitas

$\begin{array}{lccc}\text { Mariabel } & \text { Sig } & \text { Sighitung } & \text { Keterangan } \\ \text { Minat }\left(\mathrm{X}_{1}\right) & 0,05 & 0,494 & \text { Bebas Heteroskedastisitas } \\ \text { Motivasi }\left(\mathrm{X}_{2}\right) & 0,05 & 0,880 & \text { Bebas Heteroskedastisitas } \\ \text { Keputusan Memilih }(\mathrm{Y}) & 0,05 & 0,745 & \text { Bebas Heteroskedastisitas }\end{array}$

Sumber : Hasil Olah Penelitian, 2021

\section{Hasil Uji Hipotesis}

\section{Pengaruh Minat terhadap Keputusan Memilih (p 1)}

Berdasarkan output model summary tersebut besarnya adjusted R2 adalah 0,596, yang artinya pengaruh minat terhadap kepuasan memilih sebesar 59.6\% dan sisanya $40.4 \%$ dipengaruhi oleh variabel lain. Sementara $p_{1}$ dapat dilihat dari nilai Beta (Standardized coefficients) tertuang pada tabel 9 dan tabel 10 . 


\section{Pengaruh Motivasi terhadap Keputusan Memilih (p2)}

Besarnya adjusted R2 adalah 0,452, yang artinya pengaruh motivasi terhadap kepuasan memilih sebesar $45.2 \%$ dan sisanya $54.8 \%$ dipengaruhi oleh variabel lain. Sementara $p_{2}$ dapat dilihat dari nilai Beta (Standardized coefficients) tertuang pada tabel 11 dan tabel 12 .

\section{Pengaruh Pekerjaan Yang Diharapkan terhadap Keputusan Memilih (p3)}

Besaran adjusted R2 adalah 0,580, yang artinya pengaruh pekerjaan yang diharapkan terhadap keputusan memilih sebesar $58 \%$ dan sisanya $42 \%$ dipengaruhi oleh variabel lain. Sementara $p_{2}$ dapat dilihat dari nilai Beta (Standardized coefficients) tertuang pada tabel 13 dan 14 .

Tabel 9

Uji Determinasi

\begin{tabular}{crrrr} 
Model & R & R Square & $\begin{array}{c}\text { Adjusted R } \\
\text { Square }\end{array}$ & $\begin{array}{c}\text { Std. Error of the } \\
\text { Estimate }\end{array}$ \\
\hline Model Summary & & & & \\
\hline 1 & $0,779^{\mathrm{a}}$ & 0.596 & 0,605 & 1,621 \\
\hline
\end{tabular}

a. Predictors : (Constant), Minat Sumber : Hasil Olah Penelitian, 2021

Tabel 10

Uji Pengaruh

\begin{tabular}{|c|c|c|c|c|}
\hline \multirow[t]{2}{*}{ Model } & Unstandardized Coefficients & \multirow{2}{*}{$\begin{array}{c}\text { Standardized } \\
\text { Coefficients } \\
\text { Beta }\end{array}$} & \multirow[t]{2}{*}{$\mathrm{T}$} & \multirow[t]{2}{*}{ Sig } \\
\hline & Std. Error & & & \\
\hline \multicolumn{5}{|l|}{ Coefficients $^{a}$} \\
\hline (Constant) & 0.951 & & 4.575 & 0.000 \\
\hline Minat & 0.743 & 0.779 & 15.128 & 0.000 \\
\hline
\end{tabular}

Tabel 11

Uji Determinasi

\begin{tabular}{|c|c|c|c|c|}
\hline Model & $\mathrm{R}$ & R Square & $\begin{array}{l}\text { Adjusted R } \\
\text { Square }\end{array}$ & $\begin{array}{l}\text { Std. Error of the } \\
\text { Estimate }\end{array}$ \\
\hline \multicolumn{5}{|c|}{ Model Summaryb } \\
\hline 1 & $0,672^{a}$ & 0.452 & 0,448 & 1,915 \\
\hline
\end{tabular}


Tabel 12

Uji Pengaruh

\begin{tabular}{|c|c|c|c|c|c|}
\hline \multirow{2}{*}{ Model } & \multicolumn{2}{|c|}{ Unstandardized Coefficients } & \multirow{2}{*}{$\begin{array}{c}\text { Standardized } \\
\text { Coefficients } \\
\text { Beta }\end{array}$} & \multirow[t]{2}{*}{$\mathrm{T}$} & \multirow[t]{2}{*}{ Sig } \\
\hline & $\mathrm{B}$ & Std. Error & & & \\
\hline \multicolumn{6}{|l|}{ Coefficients $^{\mathrm{a}}$} \\
\hline (Constant) & 6.480 & 1.108 & & 5.851 & 0.000 \\
\hline Brand Image & 1.071 & 0.097 & 0.672 & 11.047 & 0.000 \\
\hline
\end{tabular}

a. Dependent Variable : Keputusan Memilih

Sumber : Hasil Olah Penelitian, 2021

Tabel 13

Uji Determinasi

\begin{tabular}{ccccc} 
Model & R & R Square & $\begin{array}{c}\text { Adjusted R } \\
\text { Square }\end{array}$ & $\begin{array}{c}\text { Std. Error of the } \\
\text { Estimate }\end{array}$ \\
\hline Model Summary & & & \\
\hline 1 & $0,762^{\mathrm{a}}$ & 0.580 & 0,577 & 1,676 \\
\hline a. Predictors : (Constant), Pekerjaan yang Diharapkan
\end{tabular}
Sumber : Hasil Olah Penelitian, 2021

Tabel 14

Uji Pengaruh

\begin{tabular}{|c|c|c|c|c|c|}
\hline \multirow[t]{2}{*}{ Model } & \multicolumn{2}{|c|}{ Unstandardized Coefficients } & \multirow{2}{*}{$\begin{array}{c}\text { Standardized } \\
\text { Coefficients }\end{array}$} & \multirow[t]{2}{*}{$\mathrm{T}$} & \multirow[t]{2}{*}{ Sig } \\
\hline & B & Std. Error & & & \\
\hline \multicolumn{6}{|l|}{ Coefficients $^{a}$} \\
\hline (Constant) & 4.718 & 0.768 & & 6.142 & 0.000 \\
\hline $\begin{array}{l}\text { Keputusan } \\
\text { Pembelian }\end{array}$ & 0.585 & 0.041 & 0.762 & 14.294 & 0.000 \\
\hline
\end{tabular}

a. Dependent Variable : Keputusan Memilih

Sumber : Hasil Olah Penelitian, 2021

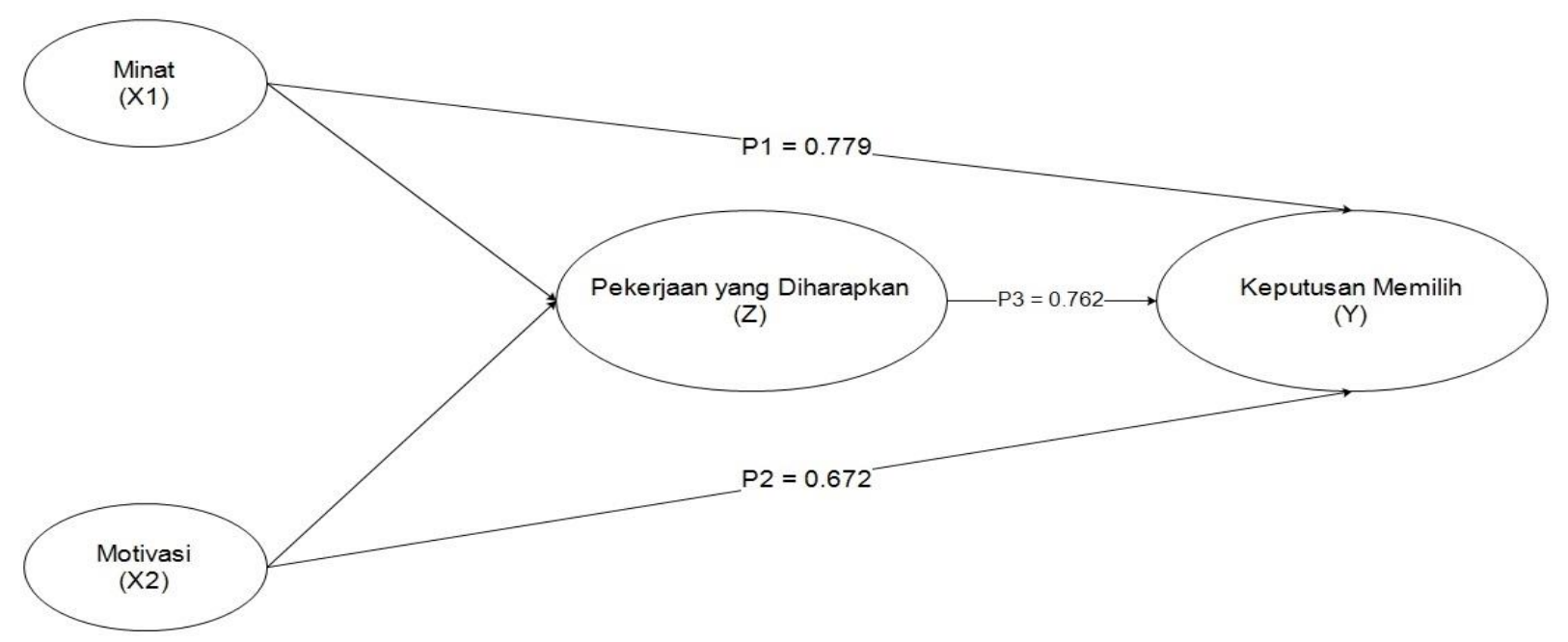

Gambar 2

Pengaruh Langsung (Direct Effect) 
Interpretasi Analisis Jalur (Path Analysis)

Guna menganalisis pengaruh mediasi antara variable X1, X2 masing-masing terhadap keputusan memilih melalui variabel pekerjaan yang diharapkan, dapat dilihat dari gambar 3. Pengaruh minat (X1) terhadap keputusan memilih melalui Pekerjaan yang diharapkan dapat dihitung dengan rumus sebagai berikut :

\section{nilai Beta $X 1$ terhadap $Z$ dikali dengan nilai Beta $Z$ terhadap $Y$}

maka $0.665 \times 0.762=0.507$. Sementara

pengaruh motivasi (X2) terhadap

keputusan memilih melalui Pekerjaan Yang diharapkan dapat dihitung dengan rumus sebagai berikut, maka $0.743 \times 0.762=$ 0.566

nilai Beta $X 2$ terhadap $Z$ dikali dengan nilai Beta $Z$ terhadap $Y$

\section{Pembahasan}

Penelitian saat ni menunjukkan bahwa terdapat pengaruh positif signifikan antara variable minat terhadap variable keputusan mahasiswa memilih Fakultas Ekonomi. Hal ini mengindikasikan semakin tinggi minat individu (mahasiswa) maka akan mendorong mereka untuk memutuskan apa yang mereka inginkan, sehingga dikatakan bahwa minat adalah salah satu factor yang mendorong seseorang untuk memilih sesuatu hal.

Peneliti telah melakukan wawancara akhir untuk mengkonfirmasi hasil penelitian ini yang berkaitan dengan minat mahasiswa, bahwa mahasiswa menyatakan bahwa alasan mereka memilih fakultas ekonomi karena ingin mendalami bidang ilmu yang mereka dapatkan semasa dibanku Sekolah Menengah Atas. Pilihan tersebut merupakan keinginan sendiri tanpa ada paksaan dari siapapun, serta sejalan dengan apa yang mereka citacitakan.

Mereka menyatakan bahwa pilihan mereka ditentukan karena kepopuleran Fakultas Ekonomi di lingkungan sekitar. Asumsi mereka Fakultas Ekonomi adalah study yang umum di masyarakat dan mereka beranggapan bahwa study di Fakultas Ekonomi dapat terjangkau oleh kondisi keuangan orang tua mereka. Hasil penelitian saat ini sejalan dengan hasil penelitian Mahanani (2018), Irmawati (2008) bahwa minat memiliki pengaruh yang signifikan terhadap keputusan mahasiswa memilih program study yang mereka inginkan. Minat memudahkan mahasiswa untuk lebih konsentrasi terhadap mata kuliah, tanpa minat maka konsentrasi terhadap pelajaran juga sulit dikembangkan dan dipertahankan. Minat 
seseorang akan timbul jika seseorang memiliki rasa senang, memiliki harapan dan memiliki pandangan akan obyek dan akan mencoba untuk mendapatkannya.

Sementara motivasi merupakan keseluruhan daya penggerak dari dalam diri siswa yang menimbulkan kegiatan belajar, yang menjamin kelangsungan dari kegiatan belajar dan yang memberikan arah pada kegiatan belajar itu. Ketika mahasiswa termotivasi untuk lebih memilih program studi yang disenangi maka ia akan berusaha untuk mendapatkannya.

Motivasi tidak dapat diamati secara langsung tapi tersimpul dari tingkah laku. Dengan memiliki motivasi yang tinggi, mahasiswa akan mempunyai ambisi untuk mendapatkan hasil yang baik dalam belajar dan bertanggung jawab terhadap diri sendiri maupun terhadap hal-hal yang telah dipercayakan kepadanya.

Hasil penelitian saat ini di temukan bahwa terdapat pengaruh positif signifikan antara variable motivasi terhadap keputusan mahasiswa dalam memilih Fakultas Ekonomi. Sama halnya dengan Setyawati et al. (2017), Mahanani (2018), Gusta et al. (2015) yang menyatakan bahwa motivasi berpengaruh signifikan terhadap keputusan mahasiswa memilih program studi. Sehingga dengan motivasi yang kuat dalam diri mahassiwa maupun dari luar akan sangat mendorong mahasiswa untuk melajutkan study mereka ke perguruan tinggi.

Hadirnya variable pekerjaan yang diharapkan dalam penelitian ini dapat memberikan informasi kepada masingmasing universitas yang menjadi objek penelitian bahwa bukan hanya berkaitan dengan factor internal mahasiswa namun terdapat factor eksternal lain yang memiliki kontribusi penting terhadap keputusan memilih para calon mahasiswa dalam menentukan pilihan mereka menempuh kuliah. Pihak universitas maupun fakultas dapat menjalin Kerjasama kepada perusahaan penyedia kerja untuk menampung lulusan berkualitas kedepannya, sehingga hal ini dapat meningkatkan minat dan motivasi dalam menentukan pilihan kuliah di universitas yang ada di Kota Bengkulu. 


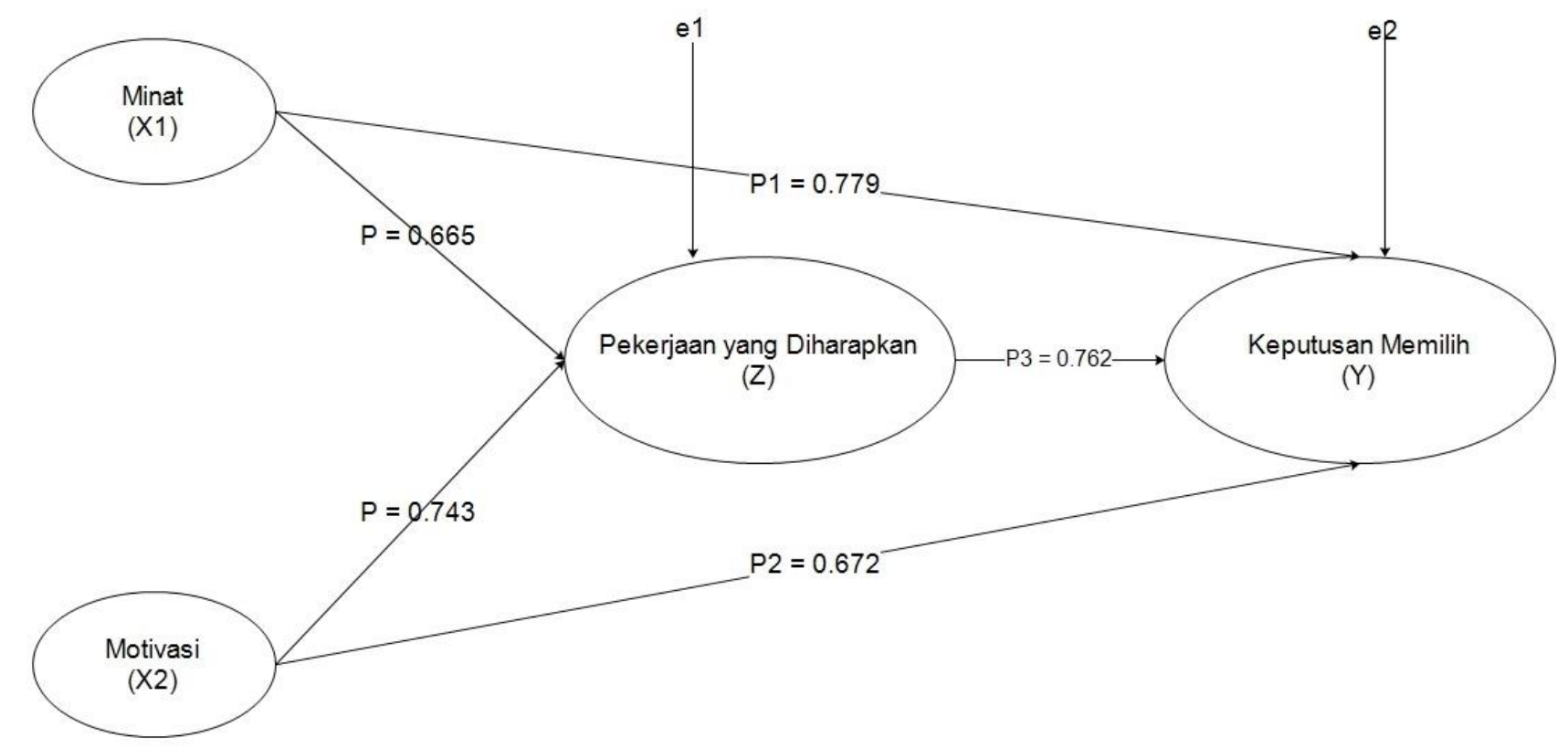

Gambar 3

Hubungan Tidak Langsung (Indirect Effect) Variabel X1, X2 Mempengaruhi Y melalui Z

\section{KESIMPULAN}

Dari hasil penelitian yang telah dipaparkan di atas maka dapat disimpulkan bahwa

1. Terdapat pengaruh signifikan antara variable minat $(\mathrm{X} 1)$ terhadap keputusan memilih (Y), dengan nilai $B=0.779$.

2. Terdapat pengaruh signifikan antara variable motivasi (X2) terhadap keputusan memilih $(\mathrm{Y})$, dengan nilai $B$ $=0.672$.

3. Terdapat pengaruh signifikan antara variable pekerjaan yang diharapkan $(\mathrm{M})$ terhadap keputusan memilih (Y), dengan nilai $B=0.762$.

4. Variable pekerjaan yang diharapkan (M) mampu memediasi antara variable minat (X1) dan variable keputusan memilih (Y), dengan nilai $B=0.507$.
5. Variable pekerjaan yang diharapkan (M) mampu memediasi antara variable minat (X1) dan variable keputusan memilih (Y), dengan nilai $B=0.566$.

\section{IMPLIKASI PENELITIAN}

Factor minat mahasiswa merupakan factor internal dalam diri mahasiswa yang tentunya sangat berpengaruh dalam pengambilan keputusan untuk memilih tempat kuliah. Kemudian faktor motivasi yang terbagi menjadi motivasi internal dan eksternal yang berasal dari lingkungan sekitar, missal fasilitas kampus. Penelitian ini membuktikan bahwa variable pekerjaan yang diharapkan dapat memediasi antara masing-masing variable $\mathrm{X} 1$ dan $\mathrm{X} 2$ terhadap variable $Y$. Variable pekerjaan 
yang diharapkan dalam penelitian ini dapat memberikan informasi kepada masing-masing universitas yang menjadi objek penelitian bahwa bukan hanya berkaitan dengan factor internal mahasiswa namun terdapat factor eksternal lain yang memiliki kontribusi penting terhadap keputusan memilih para calon mahasiswa dalam menentukan pilihan mereka menempuh kuliah.

Pihak universitas maupun fakultas dapat menjalin kerjasama kepada perusahaan penyedia kerja untuk menampung lulusan berkualitas kedepannya, sehingga hal ini dapat meningkatkan minat dan motivasi dalam menentukan pilihan kuliah di universitas yang ada di Kota Bengkulu. Hal ini dapat menjadi kontribusi bagi orgaisasi perguruan tinggi untuk memperhatikan kualitas lulusan dan penempatan lulusan dalam perusahaan tertentu. Kebijakan dapat dimulai dari menjalin kerjasama terhadap perusahaan kompeten yang dapat menampung lulusan untuk menjadi karyawan pada perusahaan mereka.

\section{ACKNOWLEDGEMENT}

Pada kesempatan ini, peneliti mengucapkan yang sebesar-besarnya kepada Kemenristek Dikti yang telah mendanai penelitian ini. Terimakasih juga peneliti ucapkan kepada Rektor Universitas Muhammadiyah Bengkulu, Ketua LPPM, dan Dekan yang telah memberikan motivasi untuk dapat dilaksanakannya penelitian ini. Terakhir peneliti ucapkan terima kasih kepada para responden (mahasiswa) yang telah membantu peneliti dalam memperoleh data penelitian ini. Semoga Allah SWT. Membalas semua kebaikan Bapak/Ibu dan mahasiswa sekalian. Aamiin Yaa Rabbal'alamiin.

\section{DAFTAR PUSTAKA}

'Amaliya, R. (2018). Faktor-Faktor Yang Mempengaruhi Keputusan Mahasiswa Dalam Menempuh Pendidikan Pada Program Studi Pendidikan Ekonomi FE UNY. Universitas Negeri Yogyakarta.

Baker, R. (2018). Understanding College Students' Major Choices Using Social Network Analysis. Research in Higher Education, 59(2), 198-225. https://doi.org/10.1007/s11162-017-9463-1

Chatfield, H. K., Lee, S. J., \& Chatfield, R. E. (2012). The Analysis of Factors Affecting Choice Of College: A Case Study Of University Of Nevada Las Vegas Hotel College Students. Journal of Hospitality and Tourism Education, 24(1), 26-33. https://doi.org/10.1080/10963758.2012.10696659

Ekowati, S. (2018). Model Of Work Family Conflict (A Study On Bank Employee In Bengkulu City). University of Bengkulu-Indonesian. 
Ekowati, S., \& Finthariasari, M. (2020). Pengaruh Harga Dan Promosi Terhadap Keputusan Pembelian Produk Pada Eleven Cafe Bengkulu. Jurnal Ilmiah Akuntansi, Manajemen, Dan Ekonomi Islam, 1(1). http://jurnal.umb.ac.id/index.php/jamekis

Fenyves, V. (2019). Analysis of Factors Influencing Foreign Studies - Strategic Decisions Results of a. Journal of Entrepreneurship Education, 22(5), 1-21.

Finthariasari, M., Ekowati, S., \& Febriansyah, E. (2020). Pengaruh Promosi, Store Atmosphere, Dan Variasi Produk Terhadap Keputusan Pembelian. Jurnal Entrepreneur Dan Manajemen Sains, 1(1).

Finthariasari, M., \& Saputri, D. (2020). Analisis Minat, Motivasi, Pekerjaan Yang Diharapkan, \& Lingkungan Belajar Terhadap Keputusan Mahasiswa Memilih Program S1 Fakultas Ekonomi (Studi Pada Mahasiswa Ekonomi Di Perguruan Tinggi Kota Bengkulu). Jurnal Manajemen Modal Insani Dan Bisnis (JMMIB), 1(2), 183-191. http://jurnal.imsi.or.id/index.php/jmmib/article/view/21

Gusta, T. I., Irda, \& Mukhtar. (2015). Pengaruh Motivasi, Persepsi Dan Sikap Terhadap Keputusan Memilih Fakultas Ekonomi Program Studi S1 Di Universitas Bung Hatta Padang. Jurnal Ekonomi Dan Bisnis, 20(40).

Irmawati, B. R. (2008). Faktor-faktor Yang Mempengaruhi Mahasiswa Dalam Memiih Program Studi [Universitas Sanata Dharma]. In Skripsi.

https://repository.usd.ac.id/7787/2/011334094_Full.pdf

Mahanani, S. (2018). Pengaruh Motivasi Dan Sikap Terhadap Keputusan Mahasiswa Dalam Memilih Jurusan Dengan Minat Sebagai Variabel Moderating Pada Universitas Islam Negeri Alauddin Makassar. Universitas Islam Negeri Alauddin Makassar.

Sahetapy, J. (2013). Diferensiasi produk, Strategi Merek, pengaruhnya terhadap keputusan pembelian sepeda Motor Yamaha Mio. Jurnal EMBA, 1(3).

Schiffman, \& Kanuk. (2004). Perilaku Konsumen (Edisi 7 (t). Prentice Hall.

Setyawati, A. (2017). Pengaruh Motivasi, Biaya Pendidikan Dan Kelompok Referensi Terhadap Keputusan Memilih Program Studi Pendidikan Ekonomi Stkip Pgri Sumatera Barat. STKIP PGRI Sumatera Barat.

Yazici, S., \& Yazici, A. (2010). Students' choice of college major and their perceived fairness of the procedure: Evidence from Turkey. Educational Research and Evaluation, 16(4), 371382. https://doi.org/10.1080/13803611.2010.528196 